\title{
A New Experimental Allergic Rhinitis Model in Mice
}

\section{Farelerde Oluşturulan Yeni Bir Alerjik Rinit Modeli}

\section{Şükran Köse $\odot$ Tuba Tatlı Kış $\odot$ Gulden Diniz $\odot$ ilkay Akbulut $\odot$ Başak Göl Serin $\odot$ Canberk Yılmaz $\odot$ Mine Özyazıcı $\odot$ Mesut Arıcı $\odot$ Aysu Yurdasiper $\odot$ Osman Yılmaz $\odot$}

\begin{abstract}
Objective: Allergic rhinitis (AR) is an inflammatory disease of the nasal mucosa mediated by IgE after exposure to an allergen. The most well known related comorbidity of AR is asthma. This study was planned due to the need for an animal model for studies on AR-asthma coexistence. In this study, the frequency of $A R$ accompanying in the asthma model created in mice, and the usability of the related model in AR studies will be investigated.

Methods: In our study, 6-8 week-old, 18-20 g BALB/c mice were used. Chicken egg ovalbumin (OVA Grade $V$, Sigma) was administered through intraperitoneal (IP) route at doses of $10 \mu \mathrm{g}$ on days 0 and 14. Mice were exposed to aerosolized $2.5 \%$ ovalbumin solution in sterile saline for 30 minutes 3 days a week for 8 weeks, starting 7 days after the last IP administration (21 st day). After exposure to OVA, mice were observed for typical signs of AR including sneezing, runny nose, and nasal itching. The final diagnosis of $A R$ was made by histopathological examination of the rhinotracheal tissues of mice.

Results: In our study, all mice exposed to ovalbumin received histopathologic diagnosis of AR. Increased number of capillaries lymphocytes, polymorphonuclear leukocytes and eosinophilsper square millimetre of rhinotracheal tissues were calculated in the murine model of AR compared to the the control group. Conclusion: This study introduced a new AR model, not cited in the literature, and induced with the longest-term ovalbumin exposure in the literature. It was concluded that this model, known as the asthma model, can also be used to induce an AR model and can be used in studies investigating coexistence of allergic rhinitis and asthma.
\end{abstract}

Keywords: Allergic rhinitis, asthma, mouse

Öz

Amaç: Alerjik rinit (AR), allerjenle karşılaştıktan sonra IgE aracılığı ile oluşan burun mukozasının inflamatuvar hastalığıdır. $A R^{\prime}$ in en iyi bilinen ve üzerinde en fazla durulan ilişkili komorbiditesi astım'dır. AR-astım birlikteliği üzerine yapılacak çalışmalar için hayvan modeli ihtiyacından dolayı bu çalışma planlanmıştır. Bu çalışmada farelerde oluşturulan astım modelinde AR'in ne sıklıkta eşlik ettiği araştırılacak olup, ilgili modelin aynı zamanda AR çalışmalarında da kullanılabilirliği araştııılacaktır.

Yöntem: Çalışmamızda 6-8 haftalık 18-20 gr ağıı̆ı̆ında, BALB/c fareler kullanılmıştır. Farelere 0. ve 14. günlerde $10 \mu \mathrm{g}$ intraperitoneal tavuk yumurtası ovalbumini (OVA Grade V, Sigma) uygulanmıştır. Son uygulamadan 7 gün sonra (21. gün) başlamak üzere, günde 30 dakika süre ile haftanın 3 günü, 8 hafta boyunca steril serum fizyolojik içindeki \%2,5'lik ovalbumin solüsyonundan oluşan aerosol inhale ettirilmiştir. Inhalasyon uygulamaları tüm vücut inhalasyon sistemi ile yapılmıştır. OVA'ya maruz kaldıktan sonra fareler hapşırma, burun akıntısı, burun kaşınması dahil AR'nin tipik belirtileri açısından gözlenmiştir. AR kesin tanısı farelerin rinotrakeal materyallerinin histopatolojik incelenmesi ile konulmuştur.

Bulgular: Çalışmamızda ovalbumine maruz bırakılan tüm fareler histopatolojik olarak AR tanısı almıştır. Bu farelerin rinotrakeal dokusunda kontrol grubundaki farelerin rinotrakeal dokusuna kıyasla AR lehine milimetrekarede artmış kapiller sayısı, lenfosit, polimorfonükleer lökosit ve eozinofil sayısı saptanmıştır. Sonuç: Bu çalışmanın literatürde en uzun süreli ovalbümin maruziyeti ile oluşturulan yeni bir AR modeli olduğu saptanmıştır. Astım modeli olarak bilinen bu modelin AR oluşturulmak için de kullanılabileceği ve astım-AR birlikteliği üzerine yapılacak çalışmalarda bu modelin kullanılabileceği sonucuna ulaşılmıştır.

Anahtar kelimeler: Alerjik rinit, astım, fare
Received: 24.02 .2021

Accepted: 19.04 .2021

First Publication: 20.09.2021

Cite as: Köse S, Tatlı Kış T, Diniz G, et al. A new experimental allergic rhinitis model in mice. İzmir Dr. Behçet Uz Çocuk Hast. Dergisi. 2021;11(3):233-9.

Tuba Tatlı Kış

Silopi Devlet Hastanesi, Enfeksiyon Hastalıkları ve Klinik Mikrobiyoloji Kliniği, Şırnak, Türkiye tubatatlii@hotmail.com ORCID: 0000-0001-6952-3748

Şükran Köse 0000-0002-4228-1213 Sağlık Bilimleri Üniversitesi, İmir Tepecik Eğitim ve Araştıma Hastanesi, Enfeksiyon Hastalıkları ve Klinik Mikrobiyoloji Kliniği, İzmir, Türkiye

Gülden Diniz 0000-0003-1512-7584 izmir Demokrasi Üniversitesi, Patoloji Anabilim Dalı, Izmir, Türkiye

ilkay Akbulut 0000-0002-4840-6865 Gümüşhane Kelkit Devlet Hastanesi, Enfeksiyon Hastalıkları ve Klinik

Mikrobiyoloji Kliniği, Gümüşhane, Türkiye

Başak Göl Serin 0000-0003-4810-3239

Balıkesir Sehir Hastanesi, Enfeksiyon Hastalıkları ve Klinik Mikrobiyoloji Kliniği, Balıkesir, Türkiye

Canberk Yilmaz 0000-0002-0049-7614 Foça Deniz Üs Komutanlığı 1. Basamak sağlık Hizmetleri, izmir, Türkiye

Mine Özyazıcı 0000-0002-3288-0685 Mesut Arıcı 0000-0002-4054-4868 Aysu Yurdasiper 0000-0001-6551-4334 Ege Üniversitesi Eczacılık Fakültesi, Farmasötik Teknoloji Anabilim Dalı, izmir, Türkiye

Osman Yilmaz 0000-0001-7817-7576 Dokuz Eylül Üniversitesi Tıp Fakültesi, Laboratuvar Hayvanları Bilimi Anabilim Dall, İzmir, Türkiye 


\section{INTRODUCTION}

Allergic rhinitis (AR) is an inflammatory disease of the nasal mucosa occurring after exposure to the allergen and mediated by immunoglobulin $E(\operatorname{IgE})^{(1)}$. The prevalence of AR in the world is $10-25 \%$ in adults and up to $40 \%$ in children, and millions of people have allergic rhinitis (2). The most well known and emphasized related comorbidity of $A R$ is asthma, and up to $85 \%$ of asthmatic patients have $A R^{(1)}$. AR and asthma are comorbidities that occur as a result of inflammation of the respiratory tract mucosa associated with similar cells and mediators, but the mechanisms by which AR and asthma occur in the same patient are still unclear.

As far as is known, in AR, the antigen binds to the IgE receptors and causes the release of histamine, prostaglandin, leukotriene and protease from the mast cells, revealing inflammation that will cause runny nose, sneezing, nasal itching, and congestion (3). This binding to IgE receptors in asthmatic patients creates acute bronchoconstriction in smooth muscles of the lower respiratory tract.

Animal models of AR are extremely important for research studies on AR. To date, guinea pigs, mice, rats and rabbits have been used in animal models of $A R^{(4-8)}$. Firstly, guinea pigs were used, and BALB/C type mice have been used mostly in recent years ${ }^{(4)}$. The reasons why mice are used in AR models are that they produce human-like IgE and are relatively cheap ${ }^{(9)}$. In various studies ovalbumin, pollen, dust mites, fungi, and schistosoma antigens have been used as allergens ${ }^{(4,6)}$. These agents were also administered as nasal drops, inhalation or multipoint subcutaneous injections to increase sensitivity ${ }^{(4)}$.

In our study, the animal model, which was created by Temelkovski J. et al. ${ }^{(10)}$ in BALB/c type mice and defined as an asthma model, was used. Our aim was to investigate whether AR also coexisted in these asthma-induced mice and whether the asthma model induced can also be used as an AR model in future studies. At the end of this study, the frequency of coexistence of AR in the murine model of asthma model, and the usability of the relevant model in AR studies and/or studies on asthma-AR coexistence will be investigated.

The aim of this study is to contribute to the literature by using a new murine model of AR. If at the end of the study, AR is induced in mice, then this animal model of AR will be defined as an AR model with the longest-term ovalbumin exposure in the literature.

\section{MATERIAL and METHOD}

A total of 22 BALB/c female 6-8- week- old mice weighing $18-20 \mathrm{~g}$ were used in the study. Before starting the study, ethics committee approval (decision no: 40/2018 date: February 24, 2021) was obtained from Dokuz Eylül University Experimental Animals Local Ethics Committee. Mice were kept individually in plastic cages on a 12 hour light/12 hour dark cycle, at $22 \pm 2^{\circ} \mathrm{C}$ room temperature and 40-50\% relative humidity.

Mice acclimated to the environment for one week were fed ad libitum with standard pellets and tap water under optimum conditions throughout the study. The asthma model developed by Temelkovski J. et al. ${ }^{(10)}$ in BALB / c mice was used.

To induce mice model of asthma, chicken egg ovalbumin (OVA Grade V, Sigma) was administered through intraperitoneal (IP) route at doses of $10 \mu \mathrm{g}$ on days 0 and 14 . Female BALB/c mice inhaled an aerosol solution consisting of $2.5 \%$ OVA in sterile saline for 8 weeks, 3 days a week for 30 minutes a day, starting 7 days after the last IP injection of OVA (day 21). Inhalation applications were performed with the whole- body exposure inhalation system.

OVA was given in a closed glass chamber through a jet nebulizer using whole-body exposure inhalation system and the particle size was below $4 \mu \mathrm{m}$ with a concentration of $10-20 \mathrm{mg} / \mathrm{m}^{3}$. After the mice models were created, the mice were sacrificed and the rhinotracheal tissue samples were evaluated histopathologically.

Randomly selected mice were divided into 3 groups.

Group 1: Sham (control) group $(n=6)$.

Group 2: Mice model of asthma was induced, and the group was sacrificed on the $74^{\text {th }}$ day $(n=7)$. 
Group 3: The asthma model was formed and the group was sacrificed on the $81^{\text {st }}$ day $(n=9)$.

\section{Evaluation of AR Symptoms}

After sensitization following exposure to OVA, mice were observed for typical signs of $A R$ including sneezing, runny, and itching nose. Nasal itch was defined as perinasal rubbing with one or both forelimbs.

\section{Histopathological evaluation}

Rhinotracheal tissue samples were evaluated histopathologically after the mice were sacrificed. All tissue samples were first fixed in a $10 \%$ formaldehyde solution for 24 hours. Following this process, the tissue samples were treated with conventional grades of alcohol $(70 \%, 80 \%, 90 \%$, and $100 \%)$ to remove the water within the tissues. The tissue samples were then passed through xylol and embedded in paraffin. Four-to-five micron sections were cut from the paraffin blocks and stained with hematoxylin-eosin. An experienced pathologist examined the histological preparations under a light microscope (Olympus BX51), and photographs were taken with an Olympus DP72 camera. Histopathological evaluation was performed by this pathologist blinded to the allocation of study groups.

Number of capillaries, lymphocytes, polymorphonuclear leukocytes (PMNLs), eosinophils per $\mathrm{mm}^{2}$ were calculated in histopathological examination.

\section{RESULTS}

\section{Clinical evaluation}

In all mice exposed to OVA, increased sneezing, rubbing perinasal area with one or both forelegs, significant increase in nasal discharge were observed compared to the control group, all of which suggested clinical symptoms of AR.

\section{Histopathological findings}

In our study, diagnosis of AR was made histopathologically in all mice exposed to OVA in Groups 2 and 3. In Groups 2 and 3, increased number of capillaries, lymphocytes, PNLs and eosinophils were found per $\mathrm{mm}^{2}$ of the rhinotracheal tissue of mice in favor of AR compared to the control group (Table 1). The increase in lymphocyte, PNL and eosinophil counts in Group 3 compared to Group 2 could be attributed to the longer exposure to ovalbumin. Although the number of capillaries in Group 3 decreased compared to Group 2, there was no statistically significant difference between the two groups. All mice that were sacrificed on the $74^{\text {th }}$ and $81^{\text {st }}$ days after exposure to OVA received the histopathologic diagnosis of AR. Considering the cost of the experiment, we thought that it will be

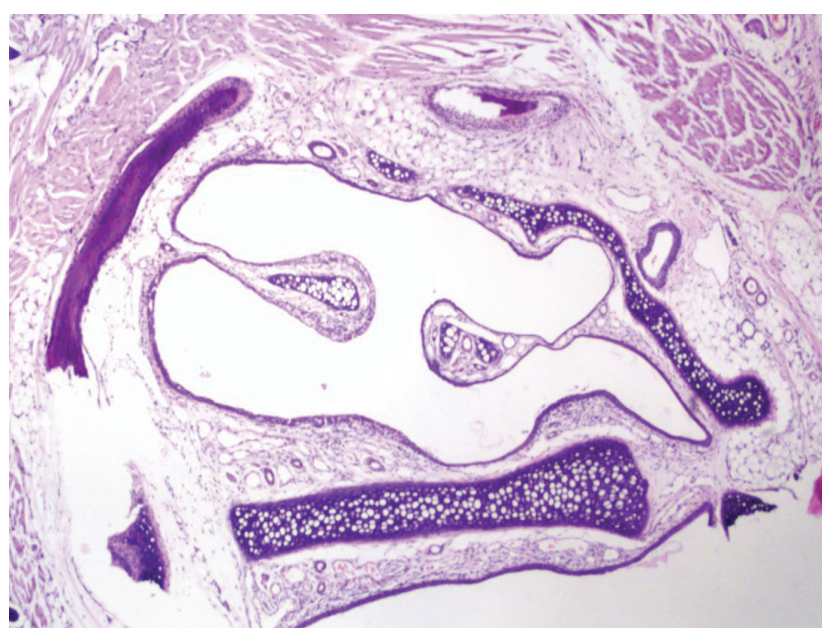

Figure 1. Cross-sectional area of nasal cavity (HEx40).

Table 1. Number of capillaries, lymphocytes, PNLs and eosinophils calculated per $\mathrm{mm}^{2}$ of rhinotracheal tissue samples of mice in Groups 1, 2 and 3.

\begin{tabular}{lcccc}
\hline & $\begin{array}{c}\text { Number of capillaries/HPF } \\
\text { mean (min-max) }\end{array}$ & $\begin{array}{c}\text { Lymphocytes } / \mathbf{m m}^{2} \\
\text { mean (min-max) }\end{array}$ & $\begin{array}{c}\text { PNLs/mm } \mathbf{m}^{2} \\
\text { mean (min-max) }\end{array}$ & $\begin{array}{c}\text { Eosinophils/mm } \\
\text { mean (min-max) }\end{array}$ \\
\hline Group 1 & $5.3(4-7)$ & $18.3(10-30)$ & $0.5(0-2)$ & $0.16(0-1)$ \\
Group 2 & $9.8(7-13)$ & $57.2(35-70)$ & $6.2(4-10)$ & $3.7(2-5)$ \\
Group 3 & $8(6-10)$ & $64.4(40-90)$ & $8.2(4-15)$ & $4(3-5)$ \\
\hline
\end{tabular}

HPF: high - power field; PNL: polymorphonuclear leukocyte. 
appropriate for the AR model to terminate the experiment on the $74^{\text {th }}$ day.

Full-thickness sections were prepared from nasal

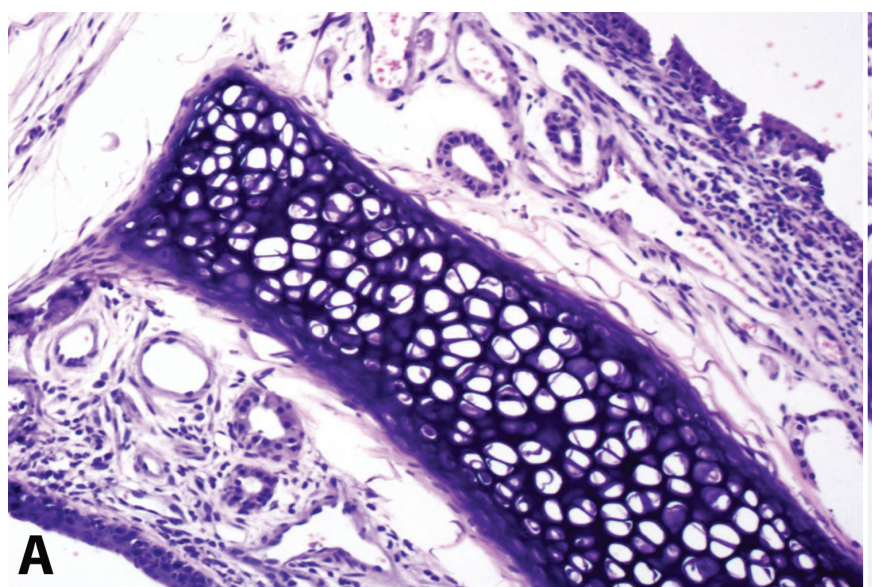

specimens obtained from mice (Figure 1). In the control, and AR groups, capillary vessels in the nasal tissue samples were countedper high-power field

Figure 2. Capillary vessels per high power field (HPF) were counted. A) A rat from the control group with 3-4 capillary vessels per HPF and B) A rat from the allergic rhinitis group with 13 capillary vessels per HPF (HEX200).

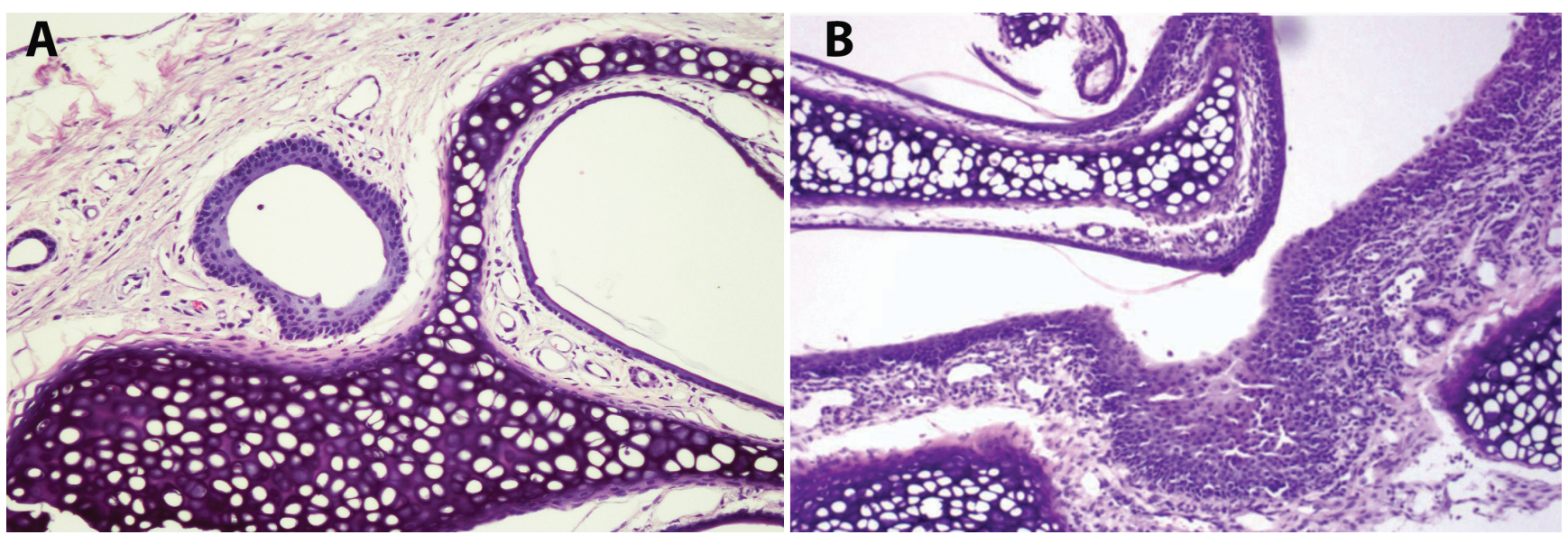

Figure 3. A) A case from the control group with mild inflammation B) A case from allergic rhinitis group with diffuse inflammation (Hex 200).

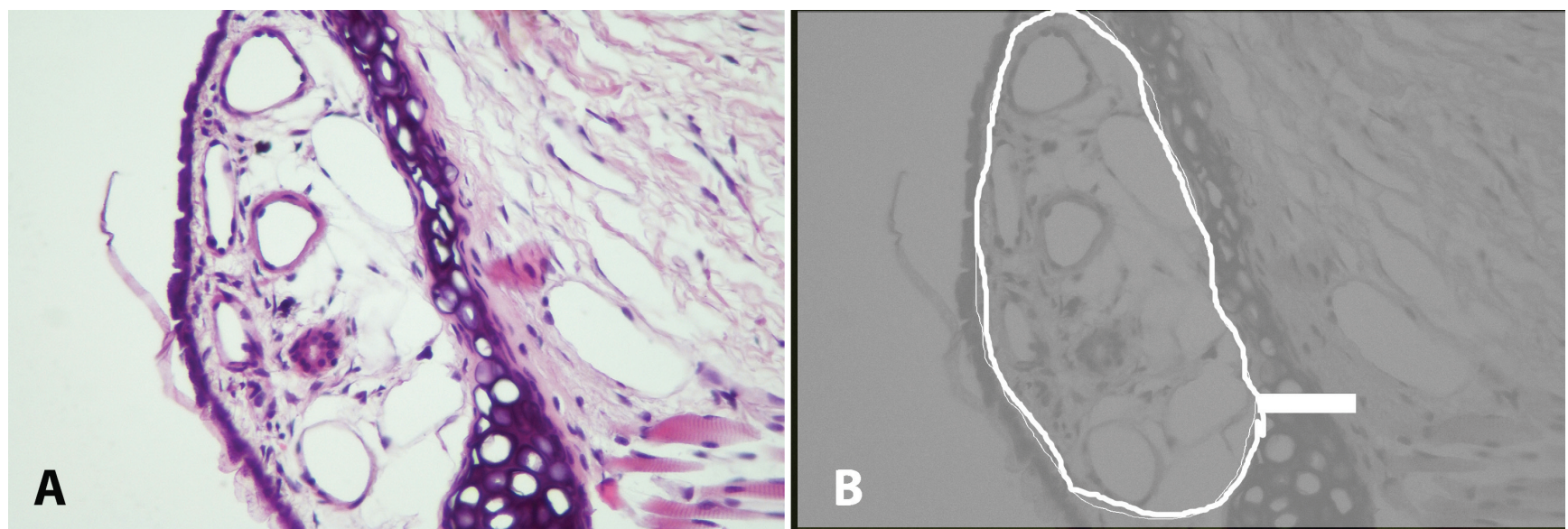

Figure 4. In all samples, a demonstrative area was selected, marked, and the inflammatory cells per $0.1 \mathrm{~mm}^{2}$ were calculated. A) A microscopic area with minimal inflammation B) Demonstration of the same area in dark-field microscopy (HEX400). 


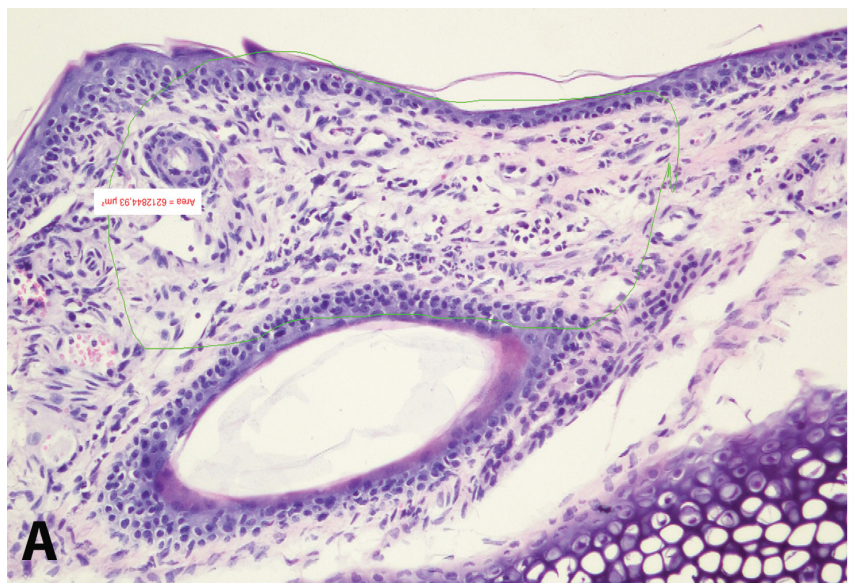

Figure 5. A) A microscopic area with severe inflammation B) Demonstration of the same area in dark-field microscopy (HEX200).
(Figure 2). A case from the control group with mild inflammation in the rhinotracheal tissue and the case from the allergic rhinitis group with intense inflammation are shown in Figure 3. In all samples, a demonstrative area was selected and marked, then inflammatory cells per $\mathrm{mm}^{2}$ were counted. Crosssectional areas with minimal (HEX400), and diffuse (HEX200) inflammation are shown in dark-field microscopy (Figures 4, and 5, respectively).

\section{DISCUSSION}

In our study, all mice exposed to OVA were clinically and histopathologically diagnosed with AR. AR models have been defined using different living species in the literature. AR has been induced by Nabe et al. ${ }^{(11)}$ by making guinea pigs to inhale the pollen of Japan cedar flower ${ }^{(12)}$. In this study, AR had been induced by dropping pollen extracts into the nostrils of guinea pigs twice a day for a total of 7 days (11). The researchers used lidocaine inhalation anesthesia to prevent the antigen from being removed by nasal ciliary activity ${ }^{(11)}$. Chen et al. ${ }^{(5)}$ reported that $A R$ was induced by IP injection of OVA on days $1,3,5,7,14$ and 21, and then instillation of intranasal OVA for seven consecutive days.

In the rabbit model of AR defined by Güneş et al. (7) $30 \mathrm{mg}$ of OVA in $100 \mathrm{~mL}$ of saline was administered intraperitoneally to rabbits every other day for 14 days. Then AR was induced in rabbits by intranasal application of OVA twice a day between the $14^{\text {th }}$ and $18^{\text {th }}$ days. In another rabbit model of $A R, A R$ was induced by IP administration of OVA on days $0,2,4$ and 6 , followed by its intranasal application for seven days ${ }^{(13)}$. In the literature, AR models have been described in rats induced by a total of 7 IP injections of OVA once a day on days 1, 3, 5, 7, 9, 11 and 13, followed by its once daily intranasal applications for 14 days ${ }^{(6,14-16)}$.

AR models are important for experimental studies performed on diagnosis and treatment of AR. Mice have been the most widely used animal species in AR models because they can be easily raised for the purpose, and often produce IgE allergens similar to humans at almost no expense ${ }^{(19)}$. AR has been induced in mice after IP injections of OVA on days 0 , 7 and 14, followed by its intranasal applications twice a day for three weeks ${ }^{(8,17)}$. Bisphenol A (BPA) has been reported to exacerbate allergic inflammation in an ovalbumin-dependent AR mouse model ${ }^{(18)}$. In this study, BPA was given to mice after they received ovalbumin IP on days 0,7 and 14. it was reported that allergic symptoms of AR were exacerbated and serum levels of OVA-specific IgE levels increased in mice ${ }^{(18)}$. In a study that investigating the effect of mesenchymal stem cells of human umbilical cord in AR treatment, IP ovalbumin was given to mice on the 0,7 , and $14^{\text {th }}$ days to induce $A R^{(19)}$. In this study, AR was induced by instilling nasal ovalbumin in mice on days 15 and $21{ }^{(19)}$. In our study, $10 \mu \mathrm{g}$ chicken egg ovalbumin (OVA Grade V, Sigma) was administered intraperitoneally to BALB/c mice on days 0 and 14 . 
Then the mice were exposed to inhaled aerosolized $2.5 \%$ OVA solution in sterile saline for 30 minutes 3 days a week for 8 weeks, starting 7 days after the last IP administration ( $21^{\text {st }}$ day). As a result, AR was induced in all mice. It has been concluded that this murine model of AR can be used in experimental studies on asthma-AR coexistence.

We think that the model we defined can be used in experimental treatment studies on AR. Kan et al. (19) used the AR model that created in mice while investigating the effect of stem cells of the umbilical cord in the treatment of AR. In this model, $25 \mu \mathrm{g}$ IP OVA was given to Balb/c strain mice on days 0,7 and 14 , followed by intranasal OVA was administered on days 15 , and $21^{(19)}$. Another study investigated the potential therapeutic effect of Metagonimus yokogawai extract on the OVA-induced allergic rhinitis model ${ }^{(20)}$. In this study, $25 \mu \mathrm{g}$ OVA were given IP 4 times on days 0, 7 and 14 to Balb/c type mice ${ }^{(20)}$. Then, AR was induced by giving intranasal OVA every day from the $25^{\text {th }}$ to the $29^{\text {th }}$ day ${ }^{(20)}$. In another study investigating the role of topical red onion extract in AR treatment, the murine AR model was used ${ }^{(21)}$. In this model, Balb/c strain mice received $25 \mu \mathrm{g}$ OVA IP on days 0,7 and $14^{(21)}$. Intranasal $100 \mu \mathrm{g}$ of OVA was administered five times a week between the days 21 and $41^{(21)}$. In another study, an AR mouse model was used to investigate the therapeutic effect of Astragalus membranaceus plant on $A R{ }^{(22)}$. In this model, IP $75 \mu \mathrm{g}$ OVA was given on days 0,7 and 14 (22). AR model was created by intranasal administration of $200 \mu \mathrm{g}$ IP OVA on days 21 and $42^{(22) .}$

In our study, $10 \mu \mathrm{g}$ chicken egg ovalbumin (OVA Grade V, Sigma) was administered to BALB/c type mice via intraperitoneal route on days 0 and 14 . Mice were made to inhale aerosolized $2.5 \%$ OVA solution in sterile saline for 30 minutes 3 days a week for 8 weeks, starting 7 days after the last IP administration $\left(21^{\text {st }}\right.$ day). As a result of this application, which was used to create a murine model of asthma in the literature, AR diagnosis was made in all mice based on clinical and histopathological findings. It was concluded that this model can also be used to create an AR model whichcan be used in studies investigating asthma-AR coexistence.
Ethics Committee Approval: The study protocol was approved by the Dokuz Eylül University Experimental Animals Local Ethics Committee (decision no: 40/2018 date: February 24, 2021).

Conflict of Interest: The authors have stated that they have no conflict of interests.

Funding: The authors declared that this study received no financial support.

\section{REFERENCES}

1. Bousquet J, Van Cauwenberge $P$, Khaltaev N. Allergic rhinitis and its impact on asthma, J. Allergy Clin. Immunol. 2001;108(5):147-334. https://doi.org/10.1067/mai.2001.118891

2. Pallasaho $P$, Juusela $M$, Lindqvist $A$, Sovijärvi $A$, Lundbäck $B$, Rönmark E. Allergic rhinoconjunctivitis doubles the risk for incident asthma--results from a population study in Helsinki. Finland. Respir Med. 2011;105:1449-56. https://doi.org/10.1016/j.rmed.2011.04.013

3. Vinke JG, KleinJan A, Severijnen LW, Hoeve LJ, Fokkens WJ. Differences in nasal cellular infiltrates between allergic children and age-matched controls. Eur Respir J. 1999;13(4):797-803.

https://doi.org/10.1034/j.1399-3003.1999.13d17.x

4. Luan ZL, Wang YN, Wang HT. Research progress of animal model of allergic rhinitis. 2016;30(13):1090-4.

https://doi.org/10.13201/j.issn.1001-1781.2016.13.022.

5. Chen M, Xu S, Zhou P, He G, Jie Q, Wu Y. Desloratadine citrate disodium injection, a potent histamine $H(1)$ receptor antagonist, inhibits chemokine production in ovalbumininduced allergic rhinitis Guinea pig model and histamineinduced human nasal epithelial cells via inhibiting the ERK1/2 and NF-kappa B signal cascades. Eur J Pharmacol. 2015;767:98-107.

https://doi.org/10.1016/j.ejphar.2015.10.014

6. Acar M, Muluk NB, Yigitaslan S, Cengiz BP, Shojaolsadati P, Karimkhani $\mathrm{H}$, et al. Can curcumin modulate allergic rhinitis in rats? J Laryngol Otol. 2016;6:1103-9. https://doi.org/10.1017/S0022215116008999

7. M.S Güneş, I Külahlı, K Kökoğlu, A Vural, D Avcl, S Güleç, et al. Evaluation of the efect of intranasal infiltrated botulinum toxin-A on a model of allergic rhinitis in rabbits: an Experimental Study, Int. J Pediatr Otorhinolaryngol. 2016;83:51-6.

https://doi.org/10.1016/j.ijporl.2016.01.010

8. Aoishi K, Takahashi H, Hato N, Gyo K, Yokota M, Ozaki S, Suzuki $M$, Treatment of allergic rhinitis with intranasal infusion of botulinum toxin type $A$ in mice. Life Sci. 2016;147:132-6. https://doi.org/10.1016/j.Ifs.2015.08.003

9. Kar M, Bayar Muluk N, Bafaqeeh SA, Cingi C. Consensus on the methodology for experimental studies in allergic rhinitis. Int J Pediatr Otorhinolaryngol. 2019;121:68-71. https://doi.org/10.1016/j.ijporl.2019.03.009

10. Temelkovski J, Hogan S, Shepherd D, Foster P, Kumar R. An improved murine model of asthma: selective airway inflammation, epithelial lesions and increased methacholine responsiveness following chronic exposure to aerosolised 
allergen. Thorax. 1998;53(10):849-56. https://doi.org/10.1136/thx.53.10.849

11. Nabe T, Mizutani N, Shimizu K, Takenaka H, Kohno S. Development of pollen-induced allergic rhinitis with early and late phase nasal blockage in guinea pigs. Inflamm Res. 1998;47:369-74. https://doi.org/10.1007/s000110050346

12. Nabe T, Kubota K, Mizutani N, Fujii M, Terada T, Takenaka H, Kohno S. Effect of local nasal immunotherapy on nasal blockage in pollen-induced allergic rhinitis of Guinea pigs. Allergol Int. 2008;57(4):419-27. https://doi.org/10.2332/allergolint.08-OA-0013

13. Yurttas V, Şereflican $M$, Erkoçoğlu $M$, Terzi EH, Kükner A, Oral M. Histopathological effects of intranasal phototherapy and nasal corticosteroids in allergic rhinitis in a rabbit model. $J$ Photochem Photobiol B. 2015;149:289-91. https://doi.org/10.1016/j.jphotobiol.2015.06.011

14. Bozdemir K, Sahin E, Altintoprak N, Muluk NB, Cengiz BP, Acar $\mathrm{M}$, et al. Is resveratrol therapeutic when used to treat allergic rhinitisinitis in rats? Clin Invest Med. 2016;39(2):E6372.

https://doi.org/10.25011/cim.v39i2.26482

15. Hancı D, Altun H, Çetinkaya EA, Muluk NB, Cengiz BP, Cingi C. Cinnamaldehyde is an effective anti-inflammatory agent for treatment of allergic rhinitis in a rat model, Int. J. Pediatr. Otorhinolaryngol. 07 Mar 2016;84:81-7. https://doi.org/10.1016/j.ijporl.2016.03.001

16. Xu YY, Liu X, Dai LB, Zhou SH. Effect of Tong Qiao drops on the expression of eotaxin, IL-13 in the nasal mucosa of rats with allergic rhinitis. J Chin Med Assoc. 2012;75:524-9. https://doi.org/10.1016/j.jcma.2012.07.003

17. Wang YX, Gu ZW, Cao ZW, Hao LY. Nonylphenol can aggravate allergic rhinitis in a murine model by regulating important Th cell subtypes and their associated cytokines. International Immunopharmacology. 2019;70:260-7. https://doi.org/10.1016/j.intimp.2019.02.030

18. Wang Y, Cao Z, Zhao H, Ren Y, Hao L, Gu Z. Bisphenol A Exacerbates Allergic Inflammation in an Ovalbumin-Induced Mouse Model of Allergic Rhinitis. J Immunol Res. 2020;2020:7573103. https://doi.org/10.1155/2020/7573103

19. Kan X, Pan X, Zhao J, He J, Cai X, Pang R, et al. Effect and mechanism of human umbilical cord mesenchymal stem cells in treating allergic rhinitis in mice. Sci Rep. 2020;10:192-5. https://doi.org/10.1038/s41598-020-76343-4

20. Yang HC, Won EJ, Kim MJ, Sung CM, Rhee JH, Nam KI. Intralymphatic Administration of Metagonimus yokogawaiExtracted Protein Attenuates Experimental Murine Allergic Rhinitis Model. Int Arch Allergy Immunol. 2020; 1-7. https://doi.org/10.1159/000511532

21. Seo MY, Kim KR, Lee JJ, Ryu G, Lee SH, Hong SD et al. Therapeutic efect of topical administration of red onion extract in a murine model of allergic rhinitis. Sci Rep. 2019;9(1):2883. https://doi.org/10.1038/s41598-019-39379-9

22. Bing $Z$, Jin-Tao Du, Feng L, Ba L, Ya-Feng L, Shi-Xi L. Effect of Astragalus membranaceus in Ovalbumin-Induced Allergic Rhinitis Mouse Model. Am J Rhinol Allergy. 2019;33(4):42032. https://doi.org/10.1177/1945892419839259 